\title{
AN ATTEMPT AT VALUATION OF WOOD FROM DEAD TREES IN POLISH FORESTS*
}

\author{
Krzysztof Adamowicz, Roman Jaszczak, Robert Kuźmiński, \\ Andrzej Łabędzki, Piotr Łakomy, Andrzej Mazur, Monika Starosta- \\ -Grala, Hubert Szramka, Mieczysław Turski, Jacek Zientarski \\ Poznań University of Life Sciences
}

\begin{abstract}
This study suggests a method of valuation for wood coming from dead trees which was applied for pricing of such wood found in Polish forests. This study shows that in Polish forest there are approx. 52 million $\mathrm{m}^{3}$ biocenotic wood coming from dead or dying trees with an estimated value of 1.5 billion PLN/10 years.
\end{abstract}

Key words: forestry economics, valuation of timber, wood from dead trees

\section{INTRODUCTION}

Forestry economy in most European countries has been facing aggravating financial problems for years. They result from the relatively limited increase or even stagnation in wood prices and growing outlays in forest economy to realise environmental and social functions of forests (Adamowicz and Dyrcz, 2008; Adamowicz, 2010). At the same time, socio-economic, ecological and cultural changes have led to modifications in the paradigm in forestry and forest economy. Several years ago most forestry enterprises (producers) worldwide focused solely on timber production, while today forest economy is multi-functional as well as economically, socially and ecologically sustainable (Harrison et al., 2002).

*The publication was created as part of the project: "The threshold values of deadwood and biodiversity of insects and fungi”, financed by the State Forests National Forest Holding.

Corresponding author - Adres do korespondencji: Dr Krzysztof Adamowicz, Department of Forest Economics, Poznań University of Life Sciences, Wojska Polskiego 71 C, 60-625 Poznań, Poland, e-mail: adamowic@up.poznan.pl

(C) Copyright by Wydawnictwo Uniwersytetu Przyrodniczego w Poznaniu 
Wood from dead trees left in the forest is one of the elements comprising the forest environment. Variation of abandoned wood in terms of their species, the degree of decomposition or the size of fragments is crucial for the maintenance of undisturbed biodiversity of forest phytocenoses (Faliński, 1978; Faliński, 1986; Sousa, 1980; White and Pickett, 1985; Siitonen et al., 2000; Bobiec, 2002; Gutowski et al., 2004; Pawicka and Woziwoda, 2011).

A lying log is a habitat for liverworts, mosses and certain vascular plants, as well as fungi and many animal species adapted to living on the substrate (Lindhe and Asenblad, 2004; Ódor and Hees, 2004; Zielonka and Piątek, 2004; Jonsson et al., 2005; Kupferschmid and Bugmann, 2005). In the opinion of Solon and Wolski (2002), the primary objective of dead wood management is to leave such a volume and quality assortments of wood, which could be sufficient to ensure continuous existence or an increase in the populations of organisms using it. Hanski and Walsh (2004) stated that resources of dead wood should be maintained at $50 \mathrm{~m}^{3} /$ ha (Pawicka and Woziwoda, 2011).

It needs to be stressed that the supply of non-production function contributes to an increase in production costs and a reduction of revenue from wood sales, which as a consequence, will be a burden to the budget of forest management units and thus will inflate operating costs for timber enterprises. However, it is necessary to incur these costs in view of the adopted paradigm for the realisation of forest economy in Europe and many countries worldwide. This problem has been indicated e.g. by Klocek and Płotkowski (1997), Hałuzo and Musiał (2004), Szramka (2004; 2011) and Adamowicz (2012). It needs to be remembered that forest economy in Poland is based on the selffinancing principles, thus when managing the forest environment we have to remember about economic conditions (Adamowicz and Kaciunka, 2014).

\section{Objective and methodology of the study}

The primary research task was to make an attempt at an valuation of wood coming from dead trees in stands in Poland, focusing on forested areas managed by the State Forests National Forest Holding.

In order to realise the primary research objective it was decided to determine the volume of timber from dead trees, establish the average price per $1 \mathrm{~m}^{3}$ for the analysed material and to determine total and 10-year value of timber from dead trees found in Polish forests.

In order to determine the volume and variation in the value of wood coming from dead coniferous and deciduous trees the guidelines presented in the Comprehensive Forest Survey in Poland (2011) were followed, i.e. coniferous species in the total volume of dead standing trees, irrespective of the type of ownership, account for $59.9 \%$. This share in the State Forests is $56.3 \%$, while in private forests it is $63.6 \%$. In the case of fallen trees lying in forests of all categories softwood accounts for $55.1 \%$, while in PGL LP it is $57.6 \%$.

In view of the fact that wood coming from dead trees is typically a material of the lowest quality, in calculations of the value of timber coming from dead standing trees we assumed the price of the medium-sized material in quality dimensional grade S4 and in the case of dead wood it was the price of small-dimensional timber. 
In order to eliminate short-term fluctuations in prices found on the market for timber (round wood) in different regions of Poland, the calculations were based on the mean price averaged from all the forest administration units in Poland. The effect of periodical fluctuations on the results was limited thanks to the application of the mean price with the equivalent prices from the two years preceding the study period (2011 and 2012).

Prices were calculated based on financial and management reports of PGL LP for the 2011 and 2012.

Similarly, as in the economic appendix prepared by BULiGL in Warsaw for the Strzelce Opolskie Forest Division (Wysocka-Fiorek, 2012), it was assumed that the mean decomposition rate of timber for wood coming from fallen dead trees and their fragments is 20 years, while for wood coming from standing dead trees and broken trees 30 years. Taking into consideration the above assumptions for the calculation of timber value in a 10-year period we applied conversion factors calculated from the quotient of the mean decomposition rate of timber and the adopted study period. For wood coming from dead standing trees this index is $0.33(10 / 30=0.33)$, while for fallen trees 0.50 $(10 / 20=0.50)$.

\section{RESULTS}

Based on the investigations conducted by the authors of this study and an analysis of available source materials it was found that in Polish forests the total volume of biocenotic wood coming from dead or dying trees is approx. 52 million $\mathrm{m}^{3}$ (Wielkoobszarowa inwentaryzacja..., 2014).

Following the adopted methodological assumptions the volume of timber coming from dead trees was determined. In absolute terms in Polish forests there are $29936471 \mathrm{~m}^{3}$ wood coming from dead fallen trees, including $21802821 \mathrm{~m}^{3}$ wood in PG LP. This total volume consists of $16494955 \mathrm{~m}^{3}$ softwood and $13441475 \mathrm{~m}^{3}$ hardwood. In the State Forests the volume of dead wood was $12558425 \mathrm{~m}^{3}$ softwood and $9244396 \mathrm{~m}^{3}$ dead wood from deciduous trees. The volume of wood from dead standing trees in all forests was $22475139 \mathrm{~m}^{3}$, while in forests administered by PGL LP it was15 118529 $\mathrm{m}^{3}$. In terms of the species composition of dead wood coming from standing trees it was found that in Polish forests there are $13462608 \mathrm{~m}^{3}$ dead softwood and $9012531 \mathrm{~m}^{3}$ hardwood. In the State Forests the volume of this type of softwood was $8511732 \mathrm{~m}^{3}$, while for softwood it was $6606797 \mathrm{~m}^{3}$.

The conducted analyses showed that the average price of fuel softwood in the years 2011-2012 was 94.00 PLN/m³ , hardwood $118.03 \mathrm{PLN} / \mathrm{m}^{3}$, while for small-sized wood it was $51.93 \mathrm{PLN} / \mathrm{m}^{3}$.

When the price and volume of wood coming from standing and fallen trees were established, the value of the above mentioned wood as raw material was determined. It was assumed that within a 10-year period the volume of wood coming from dead trees would not change drastically.

In view of the above assumptions the value of dead wood and wood from dead standing trees as raw material was determined. 
Total value of dead wood $\left(W L_{\text {total }}\right)$ :

$$
W L_{\text {total }}=29936471 \times 0.50 \times 51.93=777300469.52 \text { PLN/10 years }
$$

The value of dead wood in PGL LP (WLPGL LP):

$$
W L_{\text {PGL LP }}=21802821 \times 0.50 \times 51.93=566110247.27 \text { PLN/10 years }
$$

The value of softwood coming from dead, standing trees in Polish forests ( $\left.W D I_{\text {total }}\right)$ :

$$
W D I_{\text {total }}=13462608 \times 0.33 \times 94.00=417610100.16 \mathrm{PLN} / 10 \text { years }
$$

The value of softwood coming from dead, standing trees in PGL LP (WDIPGL LP):

$$
W D I_{\text {PGL LP }}=8511732 \times 0.33 \times 94.00=264033926.64 \mathrm{PLN} / 10 \text { years }
$$

The value of hardwood coming from dead, standing trees in Polish forests ( $\left.W D L_{\text {total }}\right)$ :

$$
W D L_{\text {total }}=9012531 \times 0.33 \times 118.03=351037181.20 \text { PLN/10 years }
$$

The value of hardwood coming from dead, standing trees in PGL LP (WDL $L_{\text {PGL LP): }}$

$$
W D L_{\mathrm{PGL} \mathrm{LP}}=6606797 \times 0.33 \times 118.03=257334082.47 \text { PLN/10 years }
$$

\section{DISCUSSION}

The primary groups of functions of forests (production and non-production) may be and are realised by each forested area. However, provision of one type of services by the forest typically requires a compromise in relation to its other functions. The extent of this compromise depends on the character of technical and economic relationships between individual functions of the forest (Płotkowski, 1994). This compromise is directly correlated with changes in the modification of the timber market (wood supply) (Adamowicz, 2012). As it was shown in the course of the research process, leaving dead trees in forested areas is of importance for the volume of timber supplied on the market.

The value of functions connected with the protection of biodiversity in forests is determined by the so-called alternative costs, manifested in the volume of lost profits (Płotkowski, 2010). Conducted analyses showed that estimated alternative costs resulting from the ecological and protective functions related to leaving wood of dead trees in Polish forests amount to over 1545 million PLN in a 10-year period, i.e. approx. 155 million PLN/year. As a result the State Forests National Forest Holding incurs losses of approx. 109 million PLN/year. Thus we need to decide whether the above mentioned amounts are high or low as the value of lost revenue resulting from the timber not being utilised. However, in view of the fact that almost $60 \%$ living organisms in the forest, to a varying degree, use resources of dead wood (Bunnell et al., 2002) it seems that the role of such wood is of great value.

When utilising commercially raw material from dead or dying trees and at the same attempting to preserve the current diversity of avifauna it seems necessary to undertake 
actions leading to the application of such substitutive measures as e.g. nest boxes. These actions are connected with certain costs and their effectiveness is frequently rather low in comparison to that of natural solutions.

At present opinions are voiced that forest economy leads to a systematic removal of trees with low economic value or constituting an apparent threat to the stability and viability of commercial forests. Preservation of the adequate sanitary condition of the forest is assured thanks to the removal of dead, dying and decaying trees, which leads to a great impoverishment of nature resources in commercial forests. Moreover, felling in stands is connected with the extraction of large-sized trees, and as such almost completely eliminates the potential for natural emergence of large volumes of dead wood (Marage and Lemperiere, 2005). Ciach (2013) presented an opinion that although at present in commercial forests we may observe considerable volumes of dead wood, they are most typically stumps left after earlier commercial management and small-sized or considerably decomposed trees as a result of natural elimination, or single shelter trees being left in accordance with management plans. As a consequence, commercial forests lack large-sized trees varying in the degree of their decomposition. As presently in Polish forests we have almost 52.5 million $\mathrm{m}^{3}$ dead wood and annually forest management units incur social costs in the form of lost profits, resulting from the decision not to utilise this wood in excess of 150 million PLN, we may hardly agree with these statements. It has to be remembered that forest economy in Poland operates on the self-financing basis. In the period of high demand for timber it is possible to incur costs connected with forest management satisfying high ecological standards. The practical implementation of the concept of sustainable development of forestry requires increased expenditure on forest economy. It turns out that management of forest ecosystems in a manner ensuring permanent multifaceted benefits from forests is much more expensive than the forest economy focused primarily on wood production. In this situation the primary economic pre-condition for the preservation of forests and their enhanced ecological function is to secure a permanent inflow of funds to run forest economy. It needs to be remembered that this activity is financed primarily by income from wood sales and to a lesser degree sale of other forestry products (Płotkowski, 2010).

However, it is commonly believed - and it needs to be accepted - that non-productive functions of forests are a multiplication of their estimated economic value. A separate problem is connected with a reliable valuation of non-productive functions and the related alternative costs, as well as willingness to accept potential social outlays, which would need to be allocated to forests as a equivalent for the social functions they serve. Šišak (2011) presented an opinion that in a multi-functional concept of forestry the economic efficiency of commercial wood production is greatly burdened with the required intensification of non-timber production functions of forests. Forest economy as an activity aiming at wood production may be considerable limited for various reasons, first of all as a result of extension of environmental functions of forests. It is becoming increasingly obvious that the commercial forest production (particularly production of timber as well as other traditional merchantable forestry products) may not be sufficient to finance the increasing social demand for non-production functions of forests in individual countries. Provision of these services usually results in increased pro- 
duction costs and reduced revenue of forest management units. For this reason forest owners and administrators have to search for other potential sources of financing of forest economy, including commercialisation of traditional non-timber products and functions of forests. For this reason when designing forest associations including biodiversity and species variation we have to remember about economic aspects, particularly market demands. In this respect we need to agree with Szczypa (2012) that proecological actions are becoming a major factor in the strategy and long-term objectives of management units.

\section{CONCLUSIONS}

The analyses and presented results of other studies concerning estimated value of timber coming from dead trees provide grounds for the following remarks and conclusions.

The current forest management meets framework conditions of multifunctional economy. In Polish forests we have approx. 52 million $\mathrm{m}^{3}$ biocenotic wood coming from dead or dying trees.

Wood of dead trees plays a key role in the maintenance of forest biodiversity, particularly in the case of saprophilous species thriving on dead wood. Maintenance of the current amounts of biocenotic timber in forests requires the decision to limit its utilisation. The estimated volume of lost revenue as a consequence of timber being left in forests as biocenotic wood in a 10 -year period amounts to over 1.5 billion PLN.

In view of the relatively little known problem of lost benefits connected with the multifunction forest economy, further detailed studies are required in this respect in order to comprehensively identify financial outlays incurred for proecological activity of forest management units. It will be of importance for pure science and education, increasing social awareness of the volume of these activities and costs incurred to maintain the current level of biodiversity in forests.

\section{SUMMARY}

Wood from dead trees plays a key role in the maintenance of forest biodiversity, particularly for species which habitat is dead wood. Maintenance of the current amount of biocenotic timber in forests is connected with failure to completely utilise it, resulting in a lack of revenue from sale of such wood. At present in Polish forests there are approx. 52 million $\mathrm{m}^{3}$ of biocenotic wood coming from dead or dying wood. Its value was determined assuming that this material may be classified to assortments with low technical quality. Based on this study it was found that estimated revenue lost as a result of timber being left in Polish forests for biocenosis conservation in a 10-year period is over 1.5 billion PLN. 


\section{REFERENCES}

Adamowicz, K. (2010). Cenowa elastyczność popytu na drewno na pierwotnym lokalnym rynku drzewnym w Polsce [Price elasticity of demand for timber on primary local wood market in Poland]. Sylwan, 154(2), 130-138.

Adamowicz, K. (2012). Ocena zmian gospodarki leśnej prowadzonej przez Państwowe Gospodarstwo Leśne Lasy Państwowe w handlu drewnem [Assessment of changes in forest economy run by the State Forests National Forest Holding in timber trade]. Poznań: Wyd. UP.

Adamowicz, K., Dyrcz, A. (2008). An attempt to assess price elasticity of demand for pine wood on the primary wood market in the Bytnica forest division in the years 1997-2005. Acta Sci. Pol. Silv. Colendar. Rat. Ind. Lignar., 7(3), 5-13.

Adamowicz, K., Kaciunka, H. (2014). Ocena tempa zmian kosztów produkcji drewna „przy pniu” i cen surowca drzewnego w latach 2001-2009 na przykładzie Regionalnej Dyrekcji Lasów Państwowych w Zielonej Górze [Assessment of rate of changes in production costs for standing timber and timber prices in the years 2001-2009 based on the Regional Directorate of State Forests in Zielona Góra]. Leśn. Pr. Bad., 75(1), 55-60.

Berg, A., Ehnström, B., Gustafsson, L., Hallingbäck, T., Jonsell, M., Weslien, J. (1994). Threatened plant, animal, and fungus species in Swedish forests: distributions and habitat associations. Conserv. Biol., 8, 718-731.

Bobiec, A. (2002). Living stands and dead wood in the Białowieża suggestions for restoration management. For. Ecol. Manag., 165, 125-140.

Bunnell, F.L., Wind, E., Boyland, M., Houde, I. (2002). Diameters and heights of trees with cavities: their implications to management. (Proceedings of the Symposium on the Ecology and Management of Dead Wood in Western Forests. Reno, NV). USDA Forest Service Gen. Tech. Rep. PSW-GTR-181, 717-737.

Ciach, M. (2013). Martwe i zamielrające drzewa w ekosystemie leśnym - ilość, jakość i zróżnicowanie [Dead and dying trees in the forest ecosystem - volume, quality and variation]. Stud. Mater. Cent. Eduk. Przyr.-Leś., 2(27), 2011, 186-199.

Faliński, J. B. (1978). Uprooted trees, their distribution and influence in the primeval forest biotope. Vegetation, 38, 175-183.

Faliński, J. B. (1986). Vegetation dynamics in temperate lowland primeval forest. Ecological Studies in Białowieża Forest. Dordrecht: Junk Publishers.

Gutowski, J. M., Bobiec, A., Pawlaczyk, P., Zub, K. (2004). Drugie życie drzewa [The second life of trees]. Warszawa: WWF Polska.

Hałuzo, M., Musiał, R. (2004). Ocena zasobów i potencjalnych możliwości pozyskania surowca dla energetyki odnawialnej w województwie pomorskim [Evaluation of stores and potential options of acquiring the raw material for renewable energetics in the Pomeranian province]. Słupsk: Biuro Planowania Przestrzennego [in Polish].

Hanski, I., Walsh, M. (2004). How much, how to? Practical tools for forest conservation. Helsinki: Bird Life European Forest Task Force.

Harmon, M. E., Cromack, Jr. K., Smith, B. G. (1987). Coarse woody debris in mixed conifer forests, Sequoia National Park, California. Can. J. For. Res., 17, 1265-1272.

Harrison, S., Herbohn, J., Niskanen, A. (2002). Consumer preferences for medicinal and aromatic plant products: Surveys of urban consumers and sellers in western Mediterranean region of Turkey. J. Med. Plants Res., 5, 2054-2063.

Heilmann-Clausen, J., Aude, E., Christensen, M. (2005). Cryptogam communities on decaying deciduous wood - does tree species diversity matter? Biodiv. Conserv., 14(9), 2061-2078.

Jonsson, B. G., Kruys, N., Ranius, T. (2005). Ecology of species living on dead wood - lessons for dead wood management. Silva Fenn., 39, 2, 289-309. 
Klock, A., Płotkowski, L. (1997). Las i jego funkcje jako dobro publiczne [Forest and its functions as a public good]. In: Las - człowiek - przyszłość. Materiały i dokumenty Kongresu Leśników Polskich, 24-26 kwietnia 1997. T. 2. Cz. 2 (pp. 149-169). Warszawa.

Kupferschmid, A. D., Bugmann, H. (2005). Effect of microsites, logs and ungulate browsing on regeneration in a mountain forest. For. Ecol. Manag., 205(1-3), 251-265.

Lindhe, A., Asenblad, N. (2004). Cut logs and high stumps of spruce, birch, aspen and oak - nine years of saproxylic fungi succession. Biol. Conserv., 119, 443-454.

Marage, D., Lemperiere, G. (2005). The management of snags: A comparison in managed and unmanaged ancient forests of the Southern French Alps. Ann. For. Sci., 62, 135-142.

Ódor, P., van Hees, A. F. M. (2004). Preferences of dead wood inhabiting bryophytes for decay stage, log size and habitat types in Hungarian beech forests. J. Bryol., 26(2), 79-95.

Pawicka, K., Woziwoda, B. (2011). Bilans martwego drewna w rezerwacie „Polesie Konstantynowskie" [Dead wood balance in the Polesie Konstantynowskie reserve]. Sylwan, 155(12), 851-858.

Płotkowski, L. (1994). Konsekwencje ekonomiczne polityki kompleksowej ochrony zasobów leśnych (uwarunkowania, problemy, trudności finansowe). In: A. Grzywacz (Ed.), Polska polityka kompleksowej ochrony zasobów leśnych (pp. 54-62) [Polish policy of comprehensive protection of forest resources (pp. 54-62)]. Warszawa: MOSZNiL.

Płotkowski, L. (2010). Ekonomiczny wymiar różnorodności biologicznej w lasach [Economic dimensions of biodiversity in forests]. Materials from a lecture. Warszawa: Kat. Urz. Lasu Geom. Ekon. Leśn. SGGW.

Siitonen, J., Martikainen, P., Punttila, P., Rauch, J. (2000). Coarse woody debris and stand characteristics in mature managed and old-growth boreal mesic forests in southern Finland. For. Ecol. Manag., 128, 211-225.

Šišak, L. (2011). Financing of Non-wood Forest Services. In: D. Lotz (Ed.), Współczesne problemy ekonomiki leśnictwa (s. 201-216). Puszczykowo: IBL.

Solon, J., Wolski, J. (2002). Propozycje gospodarowania zapasem martwego drewna w Leśnych Kompleksach Promocyjnych [Proposals for management of dead wood in Forest Promotion Complexes]. In: Podstawy trwałego i zrównoważonego zagospodarowania lasów w Leśnych Kompleksach Promocyjnych. Sękocin Las: IBL.

Sousa, W. P. (1980). The response of a community to disturbance: the importance of succession an age and species' life histories. Oecologia, 45, (72-81).

Szramka, H. (2011). Rozwój dodatkowych kierunków produkcji gospodarstwa leśnego [Development of additional directions in forestry production]. In: D. Lotz (Ed.), Współczesne problemy ekonomiki leśnictwa (pp. 332-353) [Contemporary problems in forestry economics]. Puszczykowo: IBL.

Szczypa, P. (2012). Rachunkowość zarządcza [Management accounting]. Warszawa: Wyd. CeDeWu [in Polish].

Szramka, H. (2004). Bilans otwarcia leśnictwa polskiego w momencie przystąpienia do Unii Europejskiej [Opening balance of Polish forestry at Poalnd's accession to the European Union]. Rocz. Nauk. SERiA, 6(4), 198-207.

White, P. S., Pickett, S. T. A. (1985). Natural disturbance and patch dynamics: an introduction. In: S. T. A. Pickett, P. S. White (Eds.), The ecology of natural disturbance and patch dynamics. Orlando: Academic Press.

Wielkoobszarowa inwentaryzacja stanu lasów w Polsce - wyniki za okres 2009-2013 (2014). Retrieved 2014, from www.bdl.lasy.gov.pl/portal.wisl

Wysocka-Fiorek, E. (2012). Ekspertyza ekonomiczno-techniczna dla Nadleśnictwa Strzelce Opolskie [Economic and engineering expert opinion for the Strzelce Opolskie Forest Division]. Warszawa: BULiGL.

Zielonka, T., Piątek, G. (2004). The herb and dwarf shrubs colonization of decaying logs in subalpine forest in the Polish Tatra Mountains. Plant Ecol. 172(1), 63-72. 


\title{
PRÓBA WYCENY WARTOŚCI DREWNA \\ POCHODZĄCEGO Z MARTWYCH DRZEW W POLSKICH LASACH
}

\begin{abstract}
Streszczenie. Drewno pochodzące z martwych drzew odgrywa kluczową rolę w utrzymaniu różnorodności biologicznej w lasach. Poza znaczeniem ekologicznym pozostawienie surowca drzewnego dla celów biocenotycznych ma również znaczenie ekonomiczne. Obecnie w polskich lasach jest ok. $52 \mathrm{mln} \mathrm{m}^{3}$ biocenotycznego drewna pochodzącego z martwych drzew. Jego wartość została ustalona przy założeniu, że materiał ten może być klasyfikowany do asortymentów o niskiej jakości technicznej. Na podstawie badań stwierdzono, że utracone korzyści finansowe - w wyniku pozostawienia w polskich lasach drewna biocenotycznego na ochronę biocenozy - wynoszą ponad 1,5 mld zł w okresie 10 lat.
\end{abstract}

Slowa kluczowe: ekonomika leśnictwa, wycena drewna, drewno z martwych drzew

Accepted for print - Zaakceptowano do druku: 14.04.2015

For citation - Do cytowania: Adamowicz, K., Jaszczak, R., Kuźmiński, R., Łabędzki, A., Łakomy, P., Mazur, A., Starosta-Grala, M., Szramka, H., Turski, M., Zientarski, J. (2015). An attempt at valuation of wood from dead trees in Polish forests. Acta Sci. Pol. Silv. Colendar. Rat. Ind. Lignar. 14(1), 5-13. DOI: 10.17306/J.AFW.2015.1.1 